\title{
Satellite-based assessment of climate controls on US burned area
}

\author{
D. C. Morton ${ }^{1}$, G. J. Collatz ${ }^{1}$, D. Wang ${ }^{2}$, J. T. Randerson ${ }^{3}$, L. Giglio ${ }^{2}$, and Y. Chen ${ }^{3}$ \\ ${ }^{1}$ Biospheric Sciences Laboratory, NASA Goddard Space Flight Center, Greenbelt, MD 20771, USA \\ ${ }^{2}$ Department of Geographical Sciences, University of Maryland, College Park, MD 20742, USA \\ ${ }^{3}$ Department of Earth System Science, University of California Irvine, Irvine, CA 92697, USA \\ Correspondence to: D. C. Morton (douglas.morton@nasa.gov)
}

Received: 1 June 2012 - Published in Biogeosciences Discuss.: 27 June 2012

Revised: 30 November 2012 - Accepted: 9 December 2012 - Published: 16 January 2013

\begin{abstract}
Climate regulates fire activity through the buildup and drying of fuels and the conditions for fire ignition and spread. Understanding the dynamics of contemporary climate-fire relationships at national and sub-national scales is critical to assess the likelihood of changes in future fire activity and the potential options for mitigation and adaptation. Here, we conducted the first national assessment of climate controls on US fire activity using two satellite-based estimates of monthly burned area (BA), the Global Fire Emissions Database (GFED, 1997-2010) and Monitoring Trends in Burn Severity (MTBS, 1984-2009) BA products. For each US National Climate Assessment (NCA) region, we analyzed the relationships between monthly BA and potential evaporation (PE) derived from reanalysis climate data at $0.5^{\circ}$ resolution. US fire activity increased over the past $25 \mathrm{yr}$, with statistically significant increases in MTBS BA for the entire US and the Southeast and Southwest NCA regions. Monthly PE was strongly correlated with US fire activity, yet the climate driver of PE varied regionally. Fire season temperature and shortwave radiation were the primary controls on $\mathrm{PE}$ and fire activity in Alaska, while water deficit (precipitation - PE) was strongly correlated with fire activity in the Plains regions and Northwest US. BA and precipitation anomalies were negatively correlated in all regions, although fuel-limited ecosystems in the Southern Plains and Southwest exhibited positive correlations with longer lead times (6-12 months). Fire season PE increased from the 1980's2000's, enhancing climate-driven fire risk in the southern and western US where PE-BA correlations were strongest. Spatial and temporal patterns of increasing fire season PE and BA during the 1990's-2000's highlight the potential sensitivity of US fire activity to climate change in coming decades. However, climate-fire relationships at the national scale are
\end{abstract}

complex, based on the diversity of fire types, ecosystems, and ignition sources within each NCA region. Changes in the seasonality or magnitude of climate anomalies are therefore unlikely to result in uniform changes in US fire activity.

\section{Introduction}

Climate is a fundamental constraint on fire activity. Climate conditions influence the quantity and condition of fuels (e.g., Arora and Boer, 2005; van der Werf et al., 2008b; Thonicke et al., 2010), rate of fire spread (e.g., Rothermel, 1972; Scott and Burgan, 2005), and frequency of fire ignitions from lightning (Bartlein et al., 2008; Christian et al., 2003). Globally, fires are most common in regions with intermediate levels of precipitation; fuel availability or moisture content limit fires in regions with low or high precipitation, respectively (van der Werf et al., 2008b). Human activities have amplified seasonal fire activity in temperate and tropical ecosystems (e.g., Morton et al., 2008; Giglio et al., 2006) and modified natural fire regimes through agricultural management (e.g., Le Page et al., 2010) and fire suppression efforts (Girod et al., 2007; Lenihan et al., 2008; Marlon et al., 2009). The timing, frequency, and extent of recent fires therefore reflect this complex suite of interactions among climate, ecosystems, and human societies (e.g., Thonicke et al., 2010; Giglio et al., 2006; Lavorel et al., 2007; Krawchuk et al., 2009; van der Werf et al., 2010; Kloster et al., 2010; Bowman et al., 2011; O'Connor et al., 2011).

Projections of higher fire activity under scenarios of climate change have elevated the science and policy interest in understanding climate-fire relationships (e.g., Flannigan et al., 2005; Scholze et al., 2006; Spraklen et al., 
2009; Westerling et al., 2011b; Pechony and Shindell, 2010). Fires also generate feedbacks to the climate system through changes in land surface albedo (Randerson et al., 2006) and emissions of greenhouse gases (van der Werf et al., 2010) and aerosols (Tosca et al., 2010; Seiler and Crutzen, 1980). Coupled carbon cycle and climate models that include fire illustrate the potential for fires to accelerate changes in ecosystem structure and composition expected from climate change alone (e.g., Golding and Betts, 2008; Kloster et al., 2012). Climate-driven changes in fire activity are one motivating factor for the focus on forest carbon stocks in international climate negotiations (Bonan, 2008; Malhi et al., 2008). National assessments of fire activity and climate-fire interactions are needed to connect the science and policy objectives at a common scale (e.g., CCSP, 2008; USGCRP, 2009).

In the US, regional relationships between climate and fire activity reflect a diversity of human and natural fire regimes. Previous studies were typically limited to regional analyses of climate-fire relationships because historical burned area (BA) data were unavailable at national scales (e.g., Swetnam and Betancourt, 1990; Westerling et al., 2011b; Kasischke et al., 2002). Most previous studies were also limited to forests, where stand age, charcoal records, or scarred trees retain evidence of historical fire activity (e.g., McKenzie et al., 2004).

Analyses of recent forest fires in the US highlight three broad patterns of climatic control on BA. First, summer temperatures are positively correlated with the extent of forest fires in Alaska (e.g., Kasischke and Turetsky, 2006; Kasischke et al., 2002; Duffy et al., 2005), the northwest US (McKenzie et al., 2004; Spraklen et al., 2009), and montane areas across the western US (Littell et al., 2009; Spraklen et al., 2009; Westerling et al., 2011b). Second, precipitation is a stronger control on fire activity than temperature in the southwest US (Littell et al., 2009; McKenzie et al., 2004), where long-term drought conditions (e.g., Westerling et al., 2002) and seasonal water deficits linked to early snowmelt (Westerling et al., 2006) increase regional fire activity. Third, coincident temperature and precipitation anomalies that synchronize regional fire activity in Alaska and the western US frequently coincide with large-scale climate modes, such as the Pacific Decadal Oscillation (Swetnam and Betancourt, 1990; Duffy et al., 2005; Trouet et al., 2006) and El Niño Southern Oscillation (e.g., Kitzberger et al., 2007; Heyerdahl et al., 2002; Veblen et al., 2000; Schoennagel et al., 2005). Largescale studies of climate and fire activity in other US regions are less common, and no study has used a national database of fire activity to consider fire-climate relationships in forest and non-forest ecosystems.

Satellite data provide consistent information on the spatial and temporal dynamics of recent fire activity. Active fire detections from satellite sensors offer unprecedented detail about the diurnal and seasonal distribution of global fire activity (Giglio, 2007; Giglio et al., 2006; Mu et al., 2011; Le Page et al., 2010; Chuvieco et al., 2008). Satellite-based estimates of BA integrate fire activity over time, capturing the timing, extent, and severity of burning based on pre- and post-fire imagery (e.g., Roy et al., 2008; Giglio et al., 2010). Satellite BA can be combined with land cover information to classify fires as savanna, woodland, forest, and agricultural burns, and to further distinguish forest fires between intentional deforestation and wildfires (e.g., van der Werf et al., 2010). The satellite data record of BA in savannas and woodlands is particularly valuable because the history of fire activity in these ecosystems is more difficult to determine from other proxy measures (McKenzie et al., 2004; Marlon et al., 2009; Bowman et al., 2009).

Here, we use two satellite-based estimates of monthly BA to assess climate controls on recent US fire activity. The Global Fire Emissions Database (GFED, version 3) BA product is a $14 \mathrm{yr}$ record of global fire activity (1997-2010) derived from multiple satellite data sources (Giglio et al., 2010). The GFED BA product has been used previously to understand global trends in BA (Giglio et al., 2010), and GFED emissions data have been used to evaluate climatefire relationships in equatorial Asia (van der Werf et al., 2008a) and South America (Chen et al., 2011). The Monitoring Trends in Burned Severity (MTBS) BA product (19842009) provides a longer record of large fire activity in the US based on pre- and post-fire Landsat imagery for large fires on federal and state lands (Eidenshink et al., 2007). The MTBS database offers an opportunity to evaluate the consistency of fire-climate relationships over the past $25 \mathrm{yr}$. The goal of this study was to conduct a national assessment of climate-fire relationships using satellite BA data for forest and non-forest fires. A baseline understanding of climate controls on BA is a critical precursor to assessing how future climate change may influence regional and sub-regional US fire activity. Potential evaporation (PE), calculated at $0.5^{\circ}$ resolution using reanalysis climate data, was used to integrate the influence of temperature, humidity, and other climate factors that influence monthly fire weather. Our results suggest that BA has increased in the six major US fire regions over the past $25 \mathrm{yr}$, consistent with increases in fire season PE during this period.

\section{Data and methods}

\subsection{Study area}

Relationships between monthly BA and climate variables were analysed at $0.5^{\circ}$ resolution and summarized at national and sub-national scales (Fig. 1). The US was initially divided into seven regions, as defined in the National Climate Assessment (NCA, http://assessment.globalchange. gov): Alaska and Arctic (AK), Northwest (NW), Southwest (SW), Great Plains (GP), Midwest (MW), Southeast and Caribbean (SE), and Northeast (NE). For this study, the GP region was subdivided into separate regions for the northern plains (NP) and southern plains (SP) along the Kansas-Nebraska state border to better characterize 
latitudinal changes in climate-fire relationships in the central US. These administrative regions broadly reflect climate and vegetation zones with similar climate-fire responses. Puerto Rico and the US Virgin Islands (SE region) and the Hawaii and Pacific Islands NCA region were excluded from the analysis because complete GFED and MTBS data time series were not available for these islands.

\subsection{GFED data}

GFED data provide a consistent estimate of global BA on a monthly time step. Daily BA information, based on a combination of $500 \mathrm{~m} \mathrm{BA}$ maps and active fire detections, were aggregated to monthly BA estimates at $0.5^{\circ}$ resolution (Giglio et al., 2010). Briefly, the main source of BA information for the GFED BA product was the Moderate Resolution Imaging Spectroradiometer (MODIS) direct broadcast BA algorithm (MCD64A1). During 2001-2009, > 90\% of all global BA was mapped directly using the $500 \mathrm{~m}$ MODIS product (van der Werf et al., 2010). For periods without MCD64A1 data (1997-2000, and selected months during the MODIS era), BA estimates were based on the relationship between active fire detections and MCD64A1 BA (Giglio et al., 2010). Active fire detections from MODIS, Along Track Scanning Radiometer (ATSR), and Tropical Rainfall Measurement Mission (TRMM) Visible and Infrared Scanner (VIRS) sensors complemented the available MCD64A1 data to provide consistent, gridded estimates of monthly BA for 19972010. GFED BA and emissions data are available online (www.globalfiredata.org).

Information on fire type facilitated detailed comparisons between GFED monthly BA and climate variables for the US. Beginning with version 3, GFED BA and fire emissions were partitioned into six fire types (van der Werf et al., 2010). Four of these fire types occur in the US: forest, woodland, grassland and savanna, and agricultural fires. In this study, woodland, grassland and savanna, and agricultural fires were combined into a single "herbaceous" fire category.

\subsection{MTBS data}

The MTBS project maintains the longest consistent BA time series for the entire US. Large fire perimeters in the MTBS database are derived from the combination of state and federal large fire inventories with pre- and post-fire Landsat imagery (Eidenshink et al., 2007). Large fires are defined as $>500$ ac (202 ha) in the eastern US and > 1000 ac (404 ha) in the western US, with the east-west division along the eastern border of North Dakota, South Dakota, Kansas, Oklahoma, and Texas. Many smaller fires are also included in the MTBS database, either due to differences between satellite and Incident Command System database (ICS 209) estimates of burn size, or from the National Park Service's request for an assessment of burn severity for a small fire within a National Park. Small fires accounted for approximately one quarter of all burn perimeters in the MTBS database but only $1.5 \%$ of the total burned area.

The MTBS fire perimeter data were used to assess the consistency of fire-climate relationships in the US between 1984 and 2009. MTBS fire perimeter data for 1984-2009 were downloaded from www.mtbs.gov (December 2011 data release), and MTBS fire perimeter data were aggregated to monthly BA estimates $\left(\mathrm{km}^{2}\right)$ at $0.5^{\circ}$ resolution. The fire start date was used to identify the burn month for each fire for comparisons with climate data.

\subsection{Climate data}

Climate data for this study were derived from the National Centers for Environmental Prediction (NCEP) North American Regional Reanalysis (NARR) dataset at $\sim 32 \mathrm{~km}$ spatial and 3-hourly temporal resolutions (Mesinger et al., 2006). Eleven NARR climate variables were used in this study: air temperature at $2 \mathrm{~m}, u / v$ wind speeds at $10 \mathrm{~m}$, precipitation, snow depth, relative humidity, surface pressure, albedo, surface downward shortwave radiation, and surface upward and downward longwave radiation. The entire NARR data record (1979-2010) was used as the baseline from which to estimate monthly climate variable anomalies during the GFED (19972010) and MTBS (1984-2009) time periods. NARR data were converted from Northern Lambert Conformal Conic to geographic projection for comparisons with GFED and MTBS BA data.

\subsection{Calculation of potential evaporation}

In addition to individual NARR climatic variables, monthly potential evaporation (PE) was used to represent the hydrologic demand of the atmosphere (Lu et al., 2005). PE was calculated using the Food and Agriculture Organization (FAO) version of the Penman-Monteith equation (Allen et al., 1998):

$\mathrm{PE}=\frac{\Delta\left(R_{\mathrm{n}}-G\right)+\rho_{\mathrm{a}} C_{\mathrm{p}}\left(V / r_{\mathrm{a}}\right)}{\Delta+\gamma\left(1+r_{\mathrm{s}} / r_{\mathrm{a}}\right)}$,

where $\Delta$ is the slope of the saturation pressure to temperature, $R_{\mathrm{n}}$ is the net radiation, $G$ is ground heat flux, $\rho_{\mathrm{a}}$ is air density, $C_{\mathrm{p}}$ is the specific heat of the air, $V$ is the vapour pressure deficit (VPD), $\gamma$ is the psychrometric constant, and $r_{\mathrm{s}}$ and $r_{\mathrm{a}}$ are surface and aerodynamic resistance, respectively. Except for the two resistance terms, the input parameters for Eq. (1) are constants (Allen et al., 1998) or can be calculated from the 3-hourly NARR climate variables. For this study, the bulk canopy stomatal resistance $\left(r_{\mathrm{s}}\right)$ was deemed irrelevant for fuel drying and was set to zero, and aerodynamic resistance $\left(r_{\mathrm{a}}\right)$ was calculated using the standard reference grass canopy (Allen et al., 1998). The influence of stomatal conductance on humidity and regional fire weather, likely a second order climatic control on regional BA, could be addressed in a future study. To account for non-linear variability in PE over diurnal time scales, PE was first calculated at 
the native 3-hourly time step of the NARR data and then aggregated to daily and monthly time steps. The use of PE in this study represents a methodological advance over previous studies based on empirical indices of fuel condition (e.g., Littell et al., 2009; Balshi et al., 2009) or Thornthwaite PE estimates based only on monthly air temperature, latitude, and date (e.g., Girardin and Wooton, 2009). Equation (1) mechanistically combines the interactions between temperature, solar radiation, humidity, and wind into a single variable for fuel drying potential.

\subsection{Statistical analysis}

Robust linear regression was used to calculate regional trends in $\mathrm{BA}$ and $\mathrm{PE}$, and least-squares linear regression was used to estimate correlations and cross correlations between BA and climate anomalies. Pearson's correlation coefficients between climate anomalies and BA were calculated for the peak fire month, defined as the month with the largest fraction of annual fire activity. In addition, climate-fire relationships were assessed for a 3-month fire season. The consecutive 3month period including the peak fire month with the highest fraction of annual BA was selected as the fire season. The significance of trends and correlations was assessed using a student's t-test and $95 \%$ confidence level.

The statistical approach in this study considered a range of lead times between climate and fire activity. Short lead times (0-3 months) were considered for all variables, with lead times relative to the peak fire month or the first month of the 3-month fire season. A moving 3-month window was used to aggregate climate variables for comparisons with fire-season BA. Lead times of up to 24 months were used to evaluate the influence of precipitation and snow depth on fire activity, since previous studies have shown that fuel build up and fuel drying may occur over longer time scales in water-limited systems (Westerling et al., 2003; Taylor and Beaty, 2005).

The relationships between BA and climate were initially calculated at $0.5^{\circ}$ resolution. Results were also calculated at two coarser spatial resolutions to consider sub-regional and regional relationships between climate and BA. First, BA and climate data were aggregated to $5^{\circ}$ resolution. BA at the coarser resolution was calculated as the sum of BA at the native $0.5^{\circ}$ resolution, whereas climate variables at the coarser resolution were calculated as the area-weighted average of the variable at native resolution. Second, we analyzed fireclimate relationships for each NCA region. BA and climate variables for each NCA region were aggregated from $0.5^{\circ}$ data in a similar fashion. The distributions of climate and BA at these scales supported a more robust statistical analysis, since individual $0.5^{\circ}$ grid cells may only burn once during the study period.

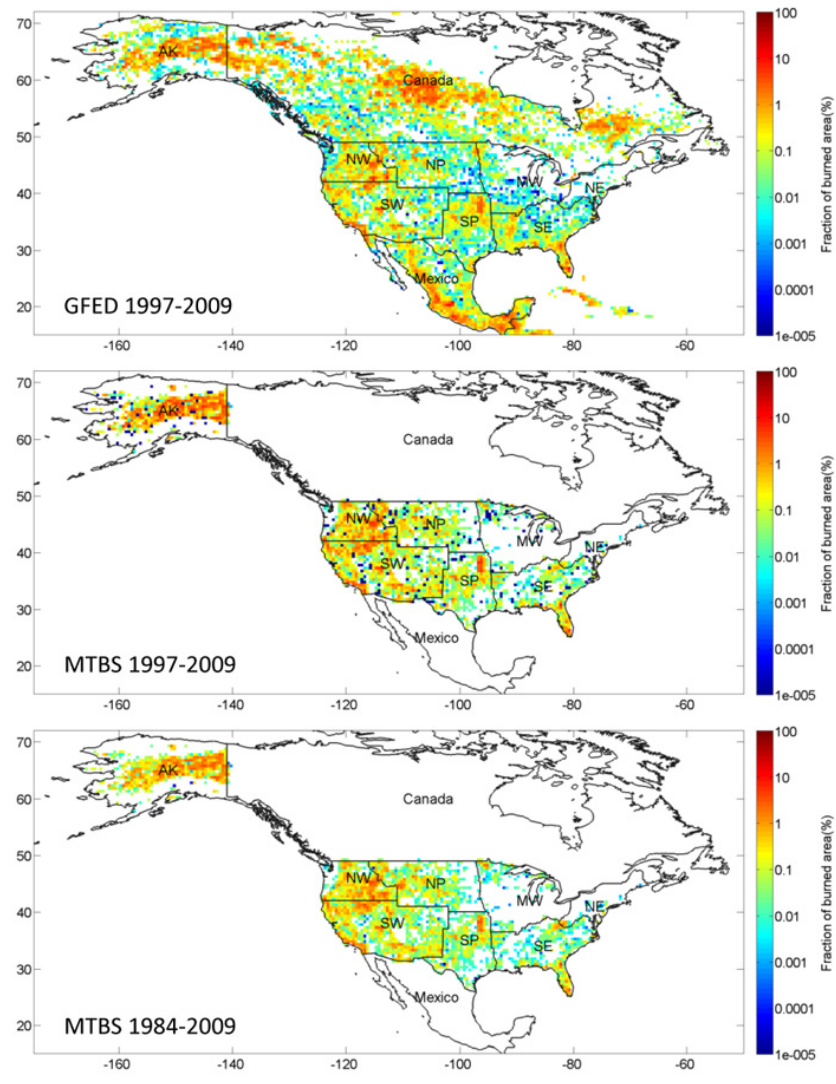

Fig. 1. Mean annual GFED BA (1997-2009, top) and MTBS BA (1997-2009, middle; 1984-2009, bottom), shown as the burned fraction of each $0.5^{\circ}$ grid cell. Sub-national study regions are outlined in black: Alaska and Arctic (AK), Northwest (NW), Southwest (SW), Northern Plains (NP), Southern Plains (SP), Midwest (MW), Southeast (SE), and Northeast (NE).

\section{Results}

\subsection{US burned area}

Satellite-based BA data offer a consistent, national perspective on US fire activity. The spatial distribution of US BA was similar for the GFED and MTBS products (Fig. 1). Within each study region, areas of concentrated fire activity appear in both datasets, including interior Alaska (AK), central Idaho (NW), southern California (SW), eastern Kansas (SP), and southern Florida (SE). Spatial patterns of recent fire activity from the MTBS data record were similar between the GFED years (1997-2009) and the full BA time series (19842009, Fig. 1). Differences between GFED and MTBS estimates of mean annual BA highlight areas with small fires or fires on private lands, including agricultural areas in the Mississippi River Valley (MW, SE) and southern Texas (SP).

The timing of recent US fire activity also varied regionally, with monthly BA peaking early in the year in the SE and SP regions and progressively later across the western US and 


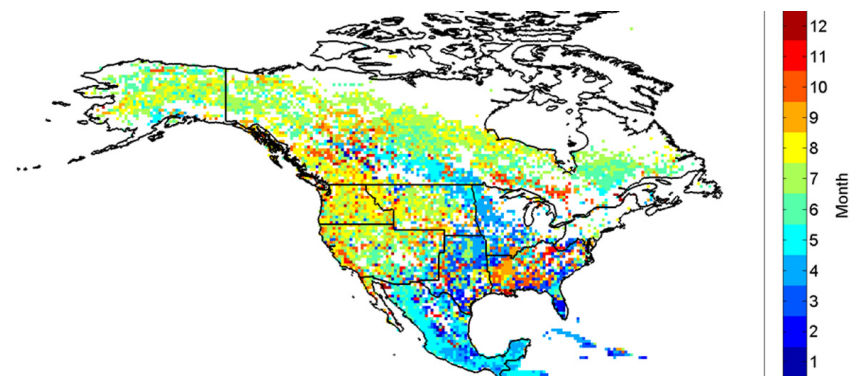

Fig. 2. Peak fire month in North America, defined as the month with the largest fraction of annual GFED burned area during 1997-2010. Colour values from 1-12 indicate the calendar month of peak fire activity for each grid cell.

Alaska (Fig. 2, Table 1). The timing of peak fire activity was more heterogeneous in the SP and SE than in other regions with substantial fire activity (Table 1). Variability in the peak fire month is consistent with a greater diversity of fire types in these regions, including fires for agricultural and forest management that do not appear in the MTBS record (Fig. 1).

Together, the spatial and temporal patterns of fire activity highlight areas where climate or management exert strong control over the burned area (Figs. 2, 3). More than $60 \%$ of the total GFED BA for the US occurred during June-August (Fig. 3). Concentrated fire activity during warmer months highlighted the importance of climate controls on BA. Six of the eight study regions had a single 3-month fire season that accounted for $>70 \%$ of mean annual BA (Table 1). Fire seasons in the other three regions did not coincide with summer months. Burning occurred year-round in the SE US, and the January-March fire season accounted for only $33 \%$ of annual BA in the SE region. Fires in the SP also peaked during drier winter months (February-April). Evidence for year-round fire activity in the SE and SP regions underscores the role of management for burning in these regions. Finally, fires were rare in the NE US (Fig. 1).

\subsection{Burned area trends}

Annual GFED BA for the US averaged $18800 \mathrm{~km}^{2} \mathrm{yr}^{-1}$ during 1997-2010 (Table 2). More than $70 \%$ of all burning during this period occurred in non-forest cover types, including woodlands, grasslands, and agricultural areas. The NW region had the highest fractional BA, with nearly $0.5 \%$ of the region burning each year (Table 2).

Six NCA regions accounted for $98 \%$ of BA in the GFED and MTBS BA time series (Table 2). The regional distribution of GFED and MTBS BA estimates were similar in four of the six major burning regions (AK, NP, NW, and $\mathrm{SW}$ ). Extensive fires for agricultural management may explain the two to threefold difference between GFED and MTBS mean annual BA estimates for the SP and SE regions (Table 2), since small fires and fires on private lands are not included in the MTBS dataset.
Table 1. Peak fire month, 3-month fire season, and the fraction of mean annual GFED BA in these months for each study region. The mean deviation in peak fire month highlights the heterogeneity of fire activity within each region.

\begin{tabular}{llrrlr}
\hline Region & $\begin{array}{l}\text { Peak Fire } \\
\text { Month }\end{array}$ & $\begin{array}{r}\text { Mean Deviation } \\
\text { (Months) }\end{array}$ & \% BA & Fire Season & $\%$ BA \\
\hline AK & Jul & 0.9 & 45.4 & Jun-Aug & 93.6 \\
NW & Aug & 0.8 & 46.4 & Jul-Sep & 85.7 \\
NP & Aug & 1.6 & 45.1 & Jul-Sept & 81.5 \\
MW & Apr & 1.5 & 39.2 & Mar-May & 71.7 \\
NE & Dec & 3.9 & 33.4 & Oct-Dec & 38.3 \\
SW & Jul & 1.4 & 27.6 & Jun-Aug & 70.0 \\
SP & Apr & 2.1 & 41.0 & Feb-Apr & 66.2 \\
SE & Feb & 3.1 & 15.0 & Jan-Mar & 33.1 \\
US & Jul & 1.8 & 25.8 & Jun-Aug & 62.2 \\
\hline
\end{tabular}

At the regional scale, BA exhibited strong interannual variability (Fig. 4). Positive BA trends were only statistically significant in the MTBS record (Table 2). Interestingly, positive MTBS BA trends were also statistically significant in the SE region and the entire US during the GFED years (19972009). MTBS BA trends $\left(\mathrm{km}^{2} \mathrm{yr}^{-1}\right)$ using robust linear regression were also larger in the GFED years (Table 2), possibly due to the lack of 2010 data for MTBS - a year with low burned area in the US.

\subsection{Climate and interannual variability in burned area}

Across the US, PE anomalies explained more variance in GFED BA than anomalies in mean monthly temperature, precipitation, VPD, or incoming shortwave radiation (Fig. 5). Correlations between $\mathrm{BA}$ and $\mathrm{PE}$ in the fire season were strongest in the NW, NP, SP, and SE regions. PE anomalies were not strongly correlated with fire season BA in portions of the SW US, where average conditions during the JuneAugust fire season are typically hot and dry. Correlations between BA and input variables for the PE Eq. (1) highlight the relative contributions of different climate drivers. The relationships between BA and VPD showed a similar spatial pattern as the BA-PE relationship but with somewhat weaker correlations in AK and the NW US (Fig. 5). Shortwave radiation and temperature were better predictors of interannual variability in BA at higher latitudes, and precipitation anomalies and BA were negatively correlated during the fire season in all regions (Fig. 5). Precipitation and associated cloudiness often reduce shortwave radiation, VPD, and temperature, causing substantial reductions in PE. Similarly, temperature, shortwave radiation, and VPD are all positively correlated with one another and negatively correlated with precipitation. This behaviour is reflected in Fig. 5, which shows strong positive correlations for VPD, temperature, and shortwave radiation and generally the strongest correlations when combined as PE. 
Table 2. Mean annual GFED (1997-2010) and MTBS (1984-2009) burned area (BA, $\mathrm{km}^{2} \mathrm{yr}^{-1}$ ) for the US and sub-national NCA regions. Mean annual BA as a fraction of the region area and trends in annual BA $\left(\mathrm{km}^{2} \mathrm{yr}^{-1}\right)$ are also shown. Asterisked values indicate statistically significant BA trends based on robust linear regression $(p<0.05)$.

\begin{tabular}{|c|c|c|c|c|c|c|c|c|c|}
\hline & AK & NW & NP & MW & $\mathrm{NE}$ & SW & SP & SE & US \\
\hline GFED Mean Annual BA $\left(\mathrm{km}^{2} \mathrm{yr}^{-1}\right)$ & 4340.9 & 2984.8 & 1461.8 & 345.5 & 53.8 & 4686.6 & 2213.5 & 2779.6 & 18866.4 \\
\hline Herbaceous BA $\left(\mathrm{km}^{2} \mathrm{yr}^{-1}\right)$ & 2407 & 2427.1 & 1126.6 & 254.8 & 34.9 & 3771.5 & 1889.1 & 1727.8 & 13638.7 \\
\hline Forest BA $\left(\mathrm{km}^{2} \mathrm{yr}^{-1}\right)$ & 1775.2 & 449.5 & 278.6 & 58.3 & 18.3 & 699.6 & 214 & 938.1 & 4431.7 \\
\hline GFED BA per unit area $(\%)$ & 0.284 & 0.474 & 0.118 & 0.029 & 0.01 & 0.264 & 0.201 & 0.206 & 0.202 \\
\hline GFED BA trend 1997-2010 $\left(\mathrm{km}^{2} \mathrm{yr}^{-1}\right)$ & 43.7 & -42.3 & 26.3 & 8.7 & -3.7 & 138.5 & 155.5 & 48.7 & 831.0 \\
\hline Herbaceous BA Trend $\left(\mathrm{km}^{2} \mathrm{yr}^{-1}\right)$ & 5.8 & -49.7 & 12.6 & 2.4 & -2.2 & 61.0 & 120.3 & 25.9 & 372.4 \\
\hline Forest BA Trend $\left(\mathrm{km}^{2} \mathrm{yr}^{-1}\right)$ & 32.0 & 7.2 & 1.7 & 5.3 & -0.7 & 31.7 & 10.4 & -11.1 & 315.3 \\
\hline MTBS Mean Annual BA $\left(\mathrm{km}^{2} \mathrm{yr}^{-1}\right)$ & 3679.2 & 2942.8 & 1506.3 & 220.7 & 103.9 & 4973.5 & 1375.9 & 1165.1 & 10993.9 \\
\hline MTBS BA per unit area (\%) & 0.24 & 0.468 & 0.122 & 0.018 & 0.02 & 0.28 & 0.125 & 0.086 & 0.118 \\
\hline MTBS Mean Annual BA (1997-2009) & 5949.8 & 3594.2 & 1741.2 & 209.6 & 43.1 & 6850.7 & 2306.7 & 1797.4 & 15642.0 \\
\hline MTBS BA per unit area (1997-2009) & 0.389 & 0.571 & 0.141 & 0.017 & 0.008 & 0.386 & 0.21 & 0.133 & 0.167 \\
\hline MTBS BA Trend 1984-2009 $\left(\mathrm{km}^{2} \mathrm{yr}^{-1}\right)$ & 11.8 & 22.7 & 28.1 & 4.5 & 0.2 & $281.0^{*}$ & 38.9 & $82.6^{*}$ & $753.0 *$ \\
\hline MTBS BA Trend 1997-2009 $\left(\mathrm{km}^{2} \mathrm{yr}^{-1}\right)$ & 505.7 & 162.3 & 58.7 & 11.4 & 0.6 & 355.9 & 123.6 & $209.9 *$ & $1809.8^{*}$ \\
\hline
\end{tabular}

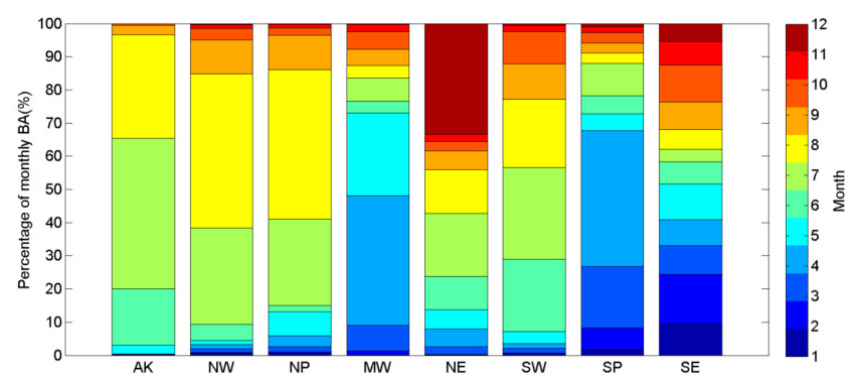

Fig. 3. Seasonal distribution of GFED BA for each US National Climate Assessment study region during 1997-2010.

The regional distribution and magnitude of correlations between MTBS BA and fire season PE were similar to patterns using the GFED data (Fig. 6). The relationship between MTBS BA and PE was stronger during the GFED years than over the entire data record, particularly in the NW and NP regions. The slope of the regression relationships provided an indication of the sensitivity of BA to recent climate conditions (Fig. 6). BA in the NW and AK regions showed the highest sensitivity to increases in fire season PE.

The lead times between monthly drying potential (PE) and BA illustrated the diversity of time scales over which climate influences fire activity (Fig. 7). Coincident $($ lead $=0)$ relationships between PE and BA were most common in regions with abundant fuels (AK, NW, and MW). Cross correlations between PE and BA in these regions decreased steadily with longer lead times, suggesting that current drying conditions are more important for monthly BA than dry conditions in previous months. In contrast, $\mathrm{PE}$ anomalies 2-6 months prior to the fire season were strongly correlated with BA in the NP and SP regions. Extended dry periods may convert live
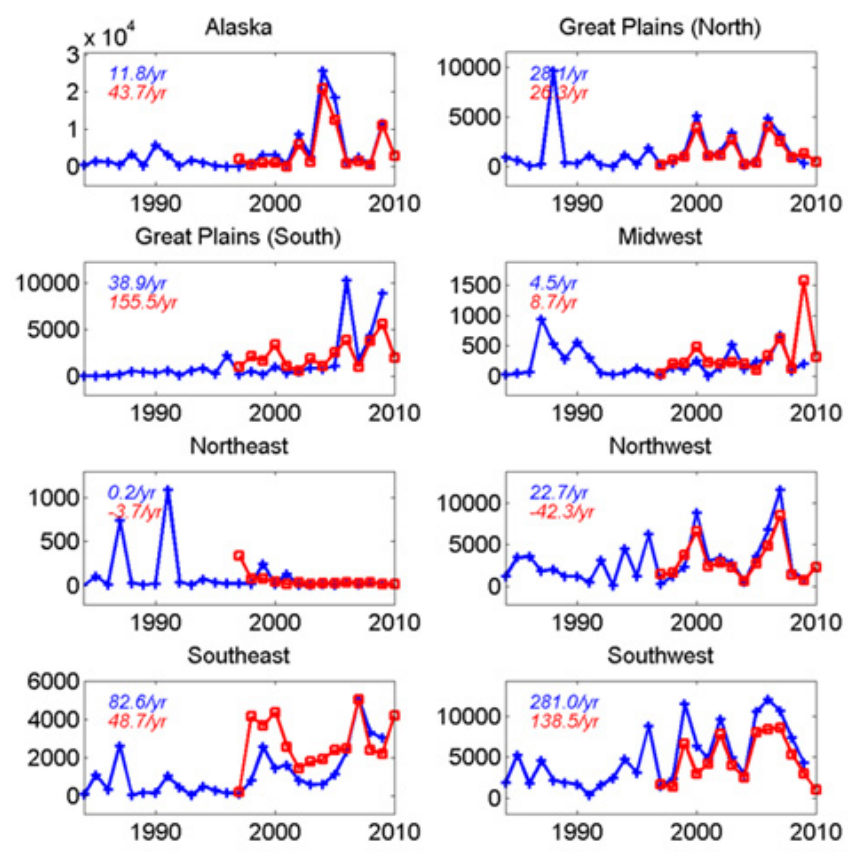

Fig. 4. Interannual variability in MTBS (blue) and GFED (red) BA for each NCA region. Values in each panel indicate the trends in annual BA $\left(\mathrm{km}^{2} \mathrm{yr}^{-1}\right)$ from robust linear regression for MTBS (1984-2009) and GFED (1997-2010) BA time series, as shown in Table 2.

plants into fine fuels in grassland and woodland ecosystems, increasing fire spread rates and BA.

Monthly relationships between MTBS BA and PE were similar to results using GFED BA data (Fig. 7). The longer MTBS data record of fires on public lands indicated shorter lead times for PE-BA cross correlations in the NP, and longer 


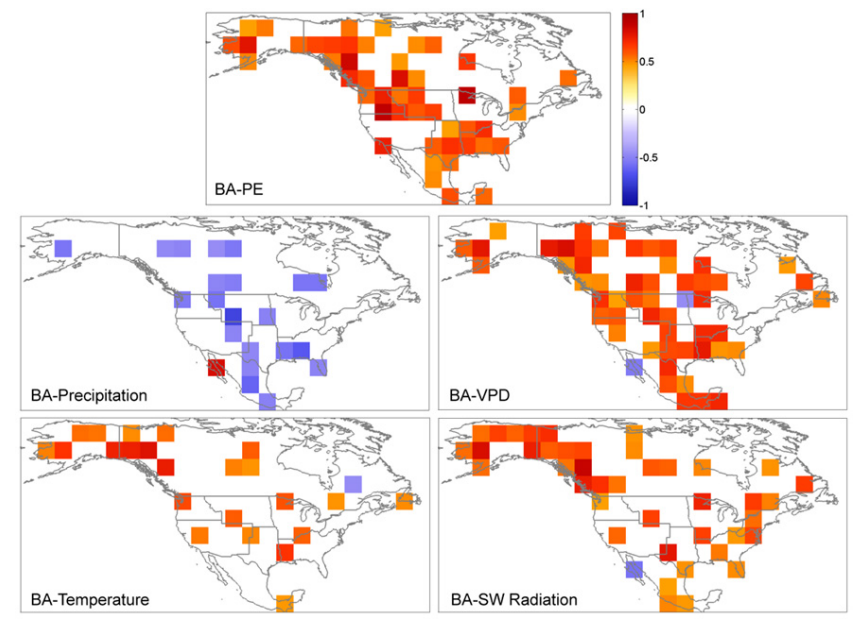

Fig. 5. Pearson's correlation coefficients for the relationships between GFED BA (1997-2010) during the 3-month fire season and climate metrics for each $5^{\circ} \times 5^{\circ}$ grid cell in North America. The colour scale indicates the Pearson's correlation coefficient $(r)$. Separate map panels show the correlation between fire-season BA and potential evaporation (PE), precipitation, vapour pressure deficit (VPD), mean monthly temperature, and incoming shortwave shortwave (SW) radiation from reanalysis climate data. Cells without statistically significant correlation coefficients $(p>0.1)$ appear white.

lead times for the maximum cross correlation between PE and BA in the SE US, similar to relationships in the Plains regions. The relationships between PE and MTBS BA across all regions were stronger for recent years (1997-2009) than during the entire MTBS time series (1984-2009), as indicated in Fig. 6.

Across the major US fire regions, monthly cross correlations between PE and BA during the fire season were statistically significant $(p<0.05)$ based on both GFED and MTBS data, especially for months with more than $20 \%$ of annual BA for a region (Fig. 7). The lack of statistically significant relationships between PE and GFED BA in two of three fire season months for the SW, SE, and MW regions suggested that other climate variables or non-climate drivers of BA such as agricultural management were more important controls on fire activity during these months.

Climate controls on PE and BA varied both within and among regions over the course of the fire season (Fig. 8). Shortwave radiation $(R)$ was the main driver of fire season $\mathrm{PE}$ in the AK, whereas the best predictor of fire season BA in the NP, SP, and NW regions was VPD or water deficit $(D)$, as a likely control on fuel availability via the conversion of live plants to fine fuels. Climatic control on monthly BA changed seasonally in the NW region, shifting from $R$ to $D$ during the fire season (Fig. 8). A similar shift occurred in the SE region from $R$ to VPD. Representation of both $R$ and VPD in the PE calculation integrated the combined influence of warming and drying conditions on BA (Fig. 7). Climate anomalies during the fire season were also important for fires in subse- quent months (e.g., AK, NW, SP), suggesting that dry conditions early in the fire season may influence the duration of the fire season later in the year.

Over longer time scales, precipitation played an important role in interannual variability of monthly BA in the SP region. Precipitation in the each of the previous two growing seasons explained nearly $30 \%$ of the variability of BA (Fig. 9). This lag between climate conditions and fire activity suggests that an increase in the interannual variability of precipitation could enhance fire activity in this region, especially in fuel-limited savanna or woodland ecosystems (e.g., Taylor and Beaty, 2005). In contrast, precipitation was more important for fire suppression than fuel accumulation in the SE region (Fig. 9). Similar lagged relationships between NARR snow depth and GFED BA for high-elevation areas in the western US and AK were not statistically significant (data not shown).

\subsection{Climate and fire risk}

PE provides an integrative measure of climate-driven fire risk. Fires occurred in grid cells with above-average monthly $\mathrm{PE}$ values in all northern regions with substantial fire activity (AK, NW, NP, MW), with the largest difference in monthly PE between fire and non-fire grid cells in AK (Fig. 10). Higher PE values for fire cells in the first month of the fire season are consistent with the need for drier conditions to accelerate the fuel drying process for early-season fires relative to later months (NP, NW, MW). The absolute value of $\mathrm{PE}$ in fire grid cells was less consistent than the tendency for above-average PE in cells with GFED BA. PE varied between $3 \mathrm{~mm} \mathrm{day}^{-1}$ for late-season fires in $\mathrm{AK}$ or early-season fires in the MW region and $>10 \mathrm{~mm} \mathrm{day}^{-1}$ for July fires in the NP.

The three southern regions exhibited contrasting patterns of monthly PE for fire grid cells compared to grid cells without GFED BA (Fig. 10). In the SE, PE values were higher in fire cells despite lower PE values during the January-March fire season than during other months of the year in this region. In the SW, PE values were also higher in fire grid cells, but the distribution of monthly PE values was more similar between fire and no-fire cells. Monthly PE values in the SW region were the highest of any region in all three months of the fire season (mean $>6 \mathrm{~mm} \mathrm{day}^{-1}$ ), consistent with other evidence (i.e., Fig. 5) that BA was less sensitive to PE anomalies in this region. Finally, PE values in the SP region were average or below average in cells with GFED BA. Fires in these months may reflect agricultural management, rather than wildfires, given differences in climate-BA cross correlations between MTBS and GFED BA for this region (Figs. 7, 8).

Climate controls on US burned area expressed as PE increased over the past $30 \mathrm{yr}$ (Fig. 11). The strongest positive trends in fire season PE occurred in the NP and MW regions. In other regions, decadal differences in PE during the fire 

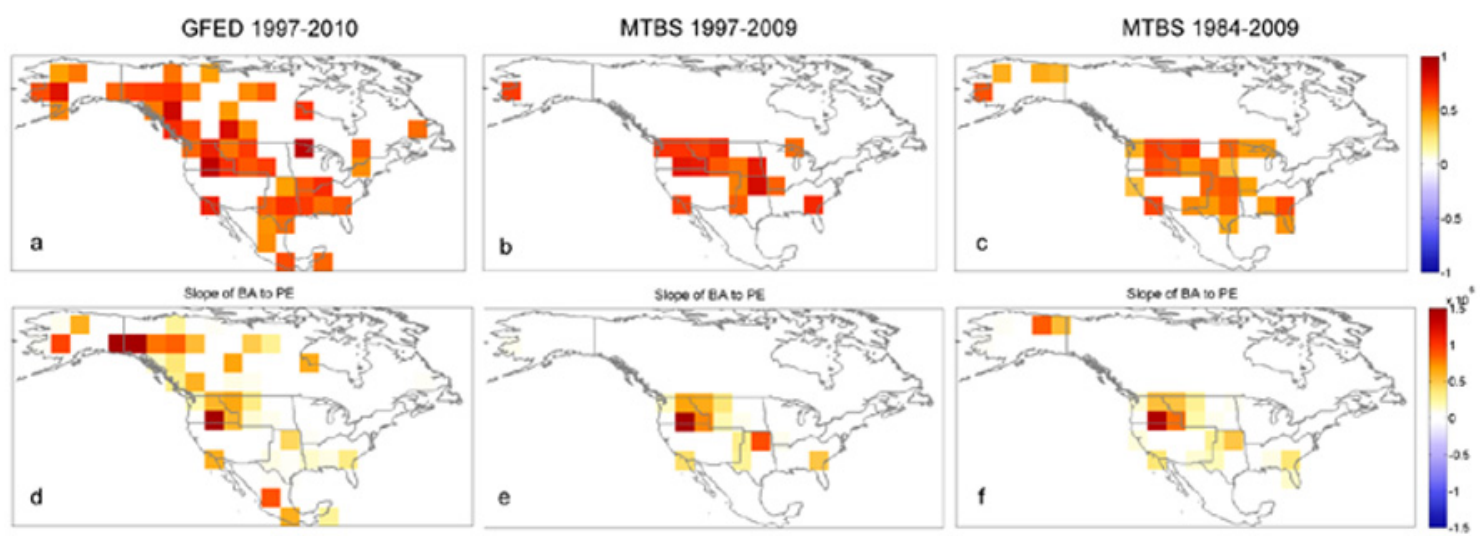

Fig. 6. Correlations between fire season PE and GFED BA (a), MTBS BA 1997-2009 (b), and MTBS BA 1984-2009 (c) for each $5^{\circ} \times 5^{\circ}$ grid cell in North America, calculated using Pearson's correlation coefficient $(r)$. Panels $\mathrm{d}-\mathrm{f}$ show the slope of the BA-PE relationships for the fire season $\left(10000 \mathrm{ha} \mathrm{mm}^{-1} \mathrm{day}^{-1}\right)$.

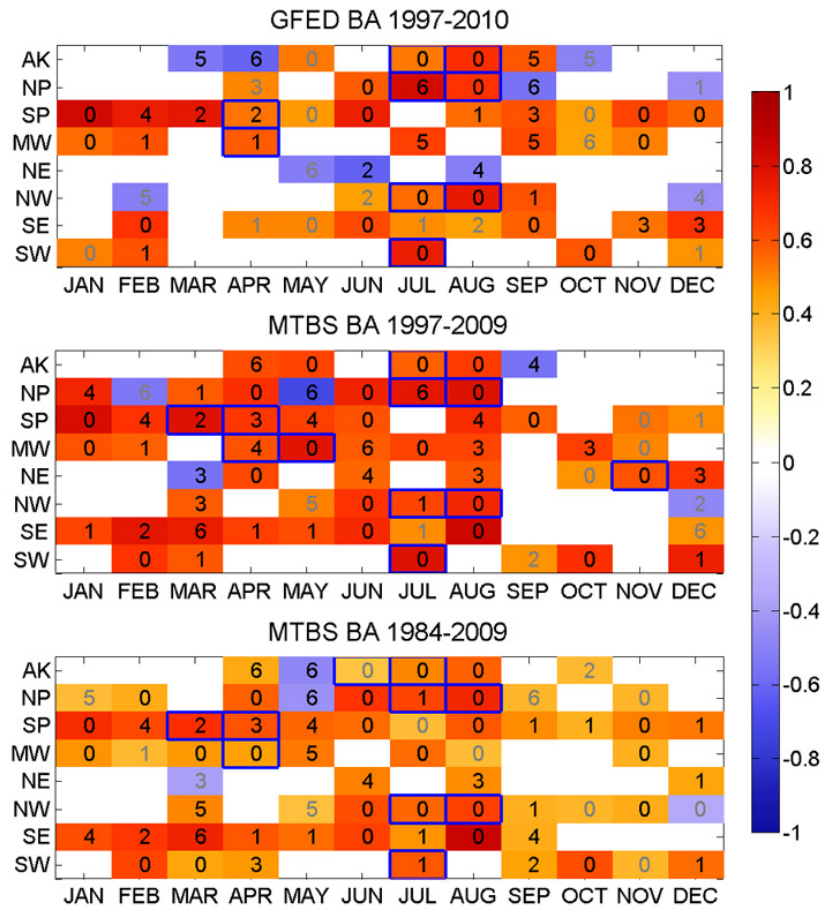

Fig. 7. Monthly cross correlation coefficients between $P E$ and GFED BA (1997-2010, top) and MTBS BA (1997-2009, middle; 1984-2009, bottom). Numbers indicate the lead time between climate and BA in months. Black text signifies Pearson's correlation coefficients with $p<0.05$, and grey text indicates correlation coefficients with $0.05 \leq p<0.1$. Months with $<2 \%$ of annual BA or months without statistically significant correlations between BA and climate variables $(p>0.1)$ appear white. Blue boxes outline months with $\geq 20 \%$ of annual BA for each region.

season were more pronounced than the $30 \mathrm{yr}$ trends. Drying potential increased between the 1980s-1990s in the SP and SW regions, with further increases in fire season PE values between the 1990s-2000s (Fig. 12). Subtle increases in fire season PE across interior AK and the SE US were also consistent over the past 30 yr (Figs. 11, 12). Fire season PE values increased for all US regions between the 1990s-2000s, with statistically significant PE increases in the AK, NP, MW, and NE regions. A strengthening relationship between climate and fire activity (Figs. 7, 12) is one potential driver of recent increases in US wildfires (Table 2).

\section{Discussion}

This study provides the first national-scale assessment of climate controls on US fire activity using satellite BA data. Satellite BA data provide unprecedented spatial and temporal detail to assess fire-climate relationships at national, regional, and sub-regional scales. Independent BA datasets from GFED and MTBS indicated increasing fire activity across the southern and western US in recent decades, with a statistically significant increase in total US BA during 19842009. Interannual variability in US BA was strongly correlated with atmospheric drying potential during the fire season. Fire season PE increased from the 1980s-2000s, enhancing climate-driven fire risk in the SP, NP, NW, and AK where PE-BA correlations were strongest. Variability in fireclimate relationships during the fire season highlighted the different time scales over which radiation, VPD, and water deficit influence the timing and duration of fire activity. This study expands upon the results of previous research on climate variability and fire activity in the US (Littell et al., 2009; Westerling et al., 2006; Xiao and Zhuang, 2007; Kloster et al., 2010) using a more mechanistic approach to estimate PE (Allen et al., 1998) and satellite-based data for monthly BA in forest and non-forest cover types. Evidence in this study for increasing climatic control on US wildfires is also consistent with previous research on temperature-driven changes in BA for Canadian boreal forests (Balshi et al., 2009; Girardin 


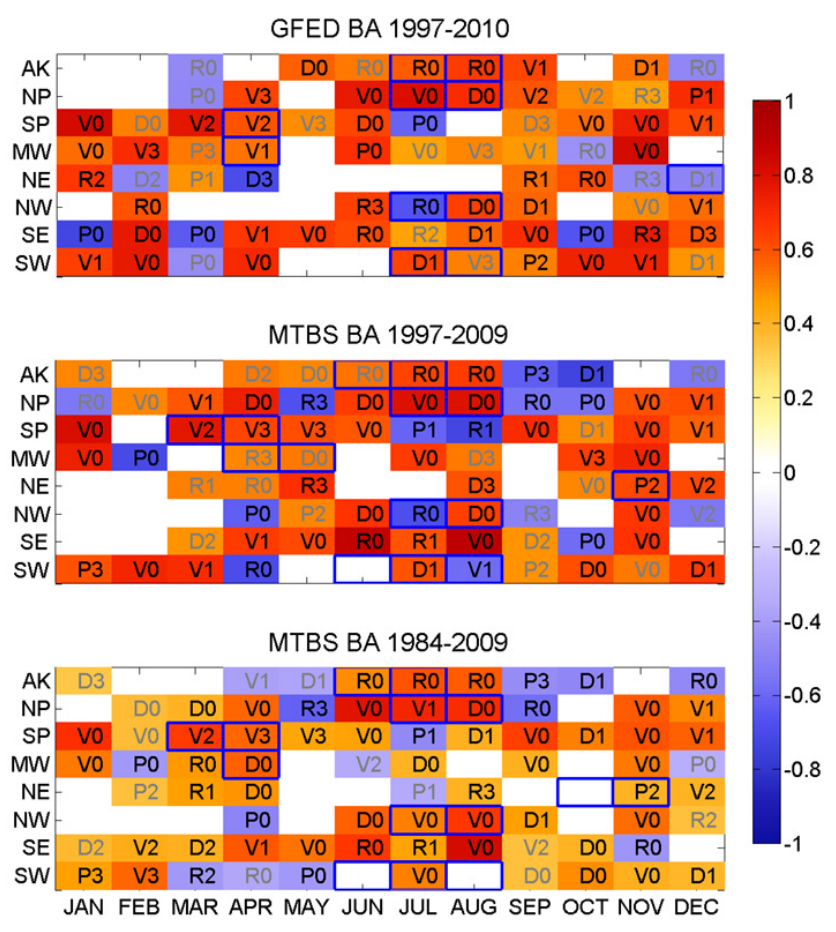

Fig. 8. Maximum monthly cross correlation coefficients between GFED (top) and MTBS (middle, 1997-2009; bottom, 1984-2009) BA and alternate climate indices. Letters in each grid cell indicate the monthly mean climate variable ( $R$ : shortwave radiation, $V$ : vapour pressure deficit, $P$ : precipitation; $D$ : water deficit, calculated as $P$-PE), numbers represent the lead time between climate and BA in months $(\max =3)$, and colours represent the Pearson's correlation coefficient. Black text indicates correlation coefficients with $p<0.05$, and grey text signifies correlation coefficients with $0.05 \leq p<0.1$. Months with $<2 \%$ of annual BA or without statistically significant correlations between BA and climate variables $(p>0.1)$ appear white. Blue boxes outline months with $\geq 20 \%$ of annual BA for each region.

and Wooton, 2009; Xiao and Zhuang, 2007; Gillett et al., 2004). The detailed PE-BA relationships in this study provide a lens for evaluating changes in the timing or duration of regional fire activity under future climate conditions.

The US experiences a complex array of fire activity, from small agricultural management fires (McCarty et al., 2007) to large wildfires in the western US and Alaska (Westerling et al., 2003; Grissino-Mayer and Swetnam, 2000; Kasischke et al., 2002). Climate-fire relationships within each NCA region were similarly complex; no single climate variable explained more than $60 \%$ of the variance in fire season BA. The PE calculation in this study captured the interactions between humidity and temperature, in addition to wind speed and net radiation, and changes in these conditions during the fire season. Fire season PE was a good predictor of interannual variability in US BA, particularly in regions such as $\mathrm{AK}, \mathrm{NW}$, and NP where either higher temperatures or lower humidity can dry existing fuels. Precipitation-fire relation-

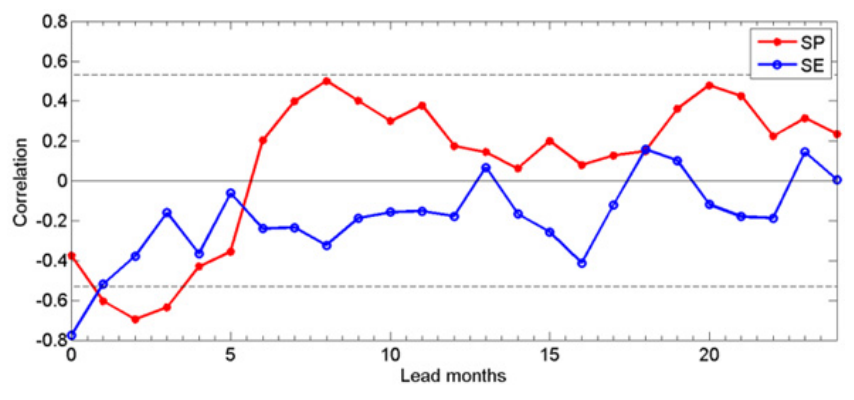

Fig. 9. Cross correlation coefficients between fire season BA and precipitation for the Southern Plains (SP) and Southeast (SE) regions for lead times of 0 to 24 months prior to the start of the fire season. Dashed lines indicate the limits for statistically significant correlation at the $95 \%$ confidence level.

ships were more variable, since precipitation can increase fire risk in fuel-limited systems in the months-years following increased rainfall (e.g., Littell et al., 2009; Westerling et al., 2003; Taylor and Beaty, 2005). Fire-climate relationships in the SW and SE regions were more difficult to generalize, given large within-region climate variability and ecosystem diversity. The distribution of peak fire month within these two regions (Fig. 2) suggests that finer spatial partitioning of fire-climate relationships may be warranted.

Differences in the climate-fire relationships between GFED and MTBS BA in this study highlight regions with human modifications of the natural fire regime. Year-round GFED fire activity in the SE US did not exhibit consistent relationships with climate variables. Seasonal differences in the timing of management fires could be used to isolate the management fire activity in BA or active fire datasets (e.g., Magi et al., 2012). Indeed, the inclusion of agricultural management fires in the GFED BA product may partially explain this variability (Giglio et al., 2010; van der Werf et al., 2010), as both climate and non-climate drivers contribute to fire activity in this region. In contrast, the MTBS record of large fires on public lands showed more consistent relationships between BA and water deficits in the SP and SE regions. Contrasting patterns of fire activity between the GFED and MTBS BA products underscore the importance of fire type on climate-fire relationships. One goal of this study was to highlight the diversity of climate-fire interactions at the national scale, including regions with few historical studies (MW, NE). The ability to capture the heterogeneity in fire activity at a region scale using satellite data provides a more complete baseline of contemporary US fire activity than in previous studies confined to regional scales (e.g., McKenzie et al., 2004; Westerling et al., 2006; Xiao and Zhuang, 2007). Further research is needed to explore the discrepancies in burned area estimates from GFED and MTBS for regions dominated by large wildfires (e.g., SW and NW regions). It is possible that differences in spatial resolution or treatment 


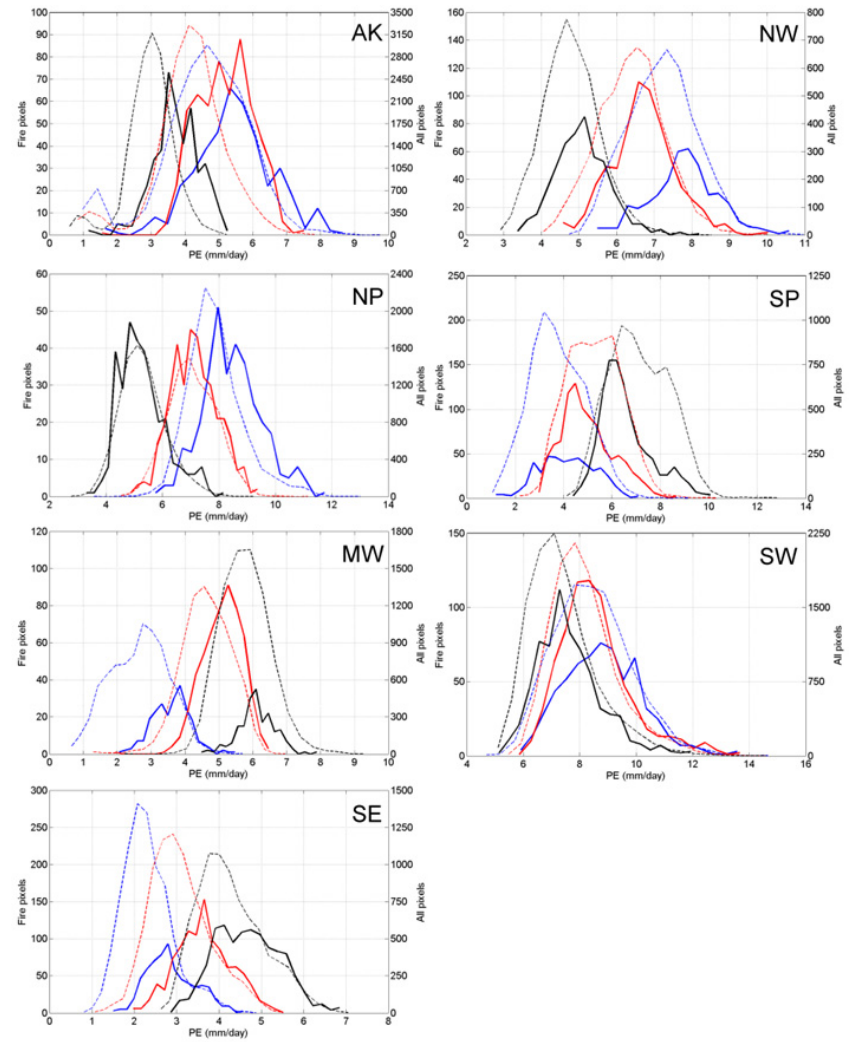

Fig. 10. Histograms of monthly PE (1997-2010) for $0.5^{\circ}$ fire grid cells (solid lines) and all grid cells (dashed lines) by region. Blue, red, and black lines indicate the first, second, and third months of the fire season, respectively (see Table 1).

of unburned islands within the fire perimeter contribute to the differences in burned area estimates.

Contemporary relationships between climate and fire provide a blueprint for assessing regional changes in US fire activity under future climate conditions. The results of this study illustrate how the spatial and temporal variability in US climate-fire relationships complicate projections of future fire activity. Increasing PE during the fire season could lead to increases in fire activity in the NP, NW, and AK. In contrast, increasing fire season PE in the SW US may have little impact on BA because mean PE values during the fire season are already favourable for fire activity. BA in the SP region responded to short-term water deficits and long-term anomalies in precipitation, such that increasing interannual variability in precipitation could lead to additional fires in the region. Thus, changes in the seasonality or magnitude of climate anomalies are unlikely to result in uniform changes in US fire activity. The results of this study could be used to identify region-specific relationships between climate and BA to improve the parameterization of models that project future fire activity.

Recent efforts to model US fire activity under scenarios of climate change project a climate-driven increase in the area
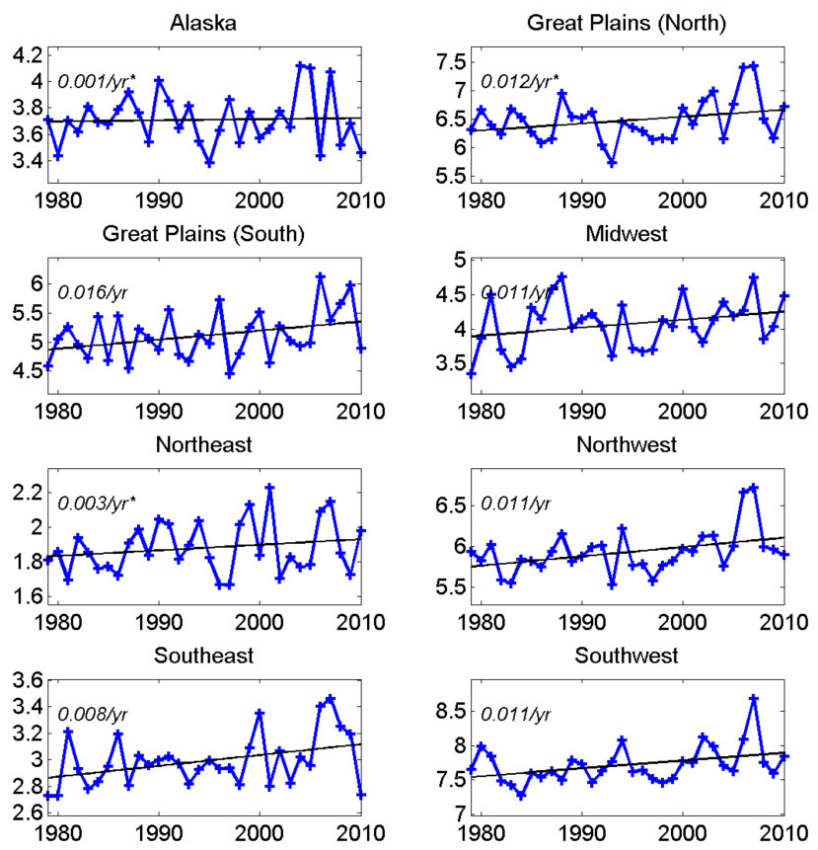

Fig. 11. Fire season PE (+) for each NCA region between 1980 and 2010. Values indicate the linear trends in fire season PE (black lines) during this period. Starred values indicate statistically significant PE trends based on robust linear regression $(p<0.05)$.

and severity of wildfires (e.g., Brown et al., 2004; Spraklen et al., 2009; Westerling et al., 2011a). Different projections of future fire activity depend, in large part, on the complexity of the fire-climate feedbacks in the model. Models that simulated the response of vegetation and fire to climate warming suggest that some of the increase in net carbon losses from wildfire could be offset by enhanced vegetation growth (Bachelet et al., 2005) or by the combination of enhanced vegetation growth plus fire suppression efforts (Lenihan et al., 2008; Rogers et al., 2011). Coupled models of the climate system with projections of population, land use, and wildfires also highlight the likely increase in US fire activity under scenarios of land use and climate change (Pechony and Shindell, 2010). However, studies that include other direct and indirect climate feedbacks from fire are still needed, such as the impacts of aerosols and long-lived trace gases (Seiler and Crutzen, 1980; Andreae and Merlet, 2001; van der Werf et al., 2010), albedo changes (Randerson et al., 2006), and hydrological exchanges between the land surface and atmosphere (Busch and Smith, 1993; Kang et al., 2006).

Five methodological limitations in this study could be addressed in future research. First, fire activity reflects the influence of climate anomalies over a range of temporal and spatial scales (Parisien et al., 2011). The use of monthly PE values in this study does not capture synoptic events or longer-term evolution of climate phenomena, including carryover effects from anomalies in previous months such as soil water deficits. Second, climate controls on fire ignitions 


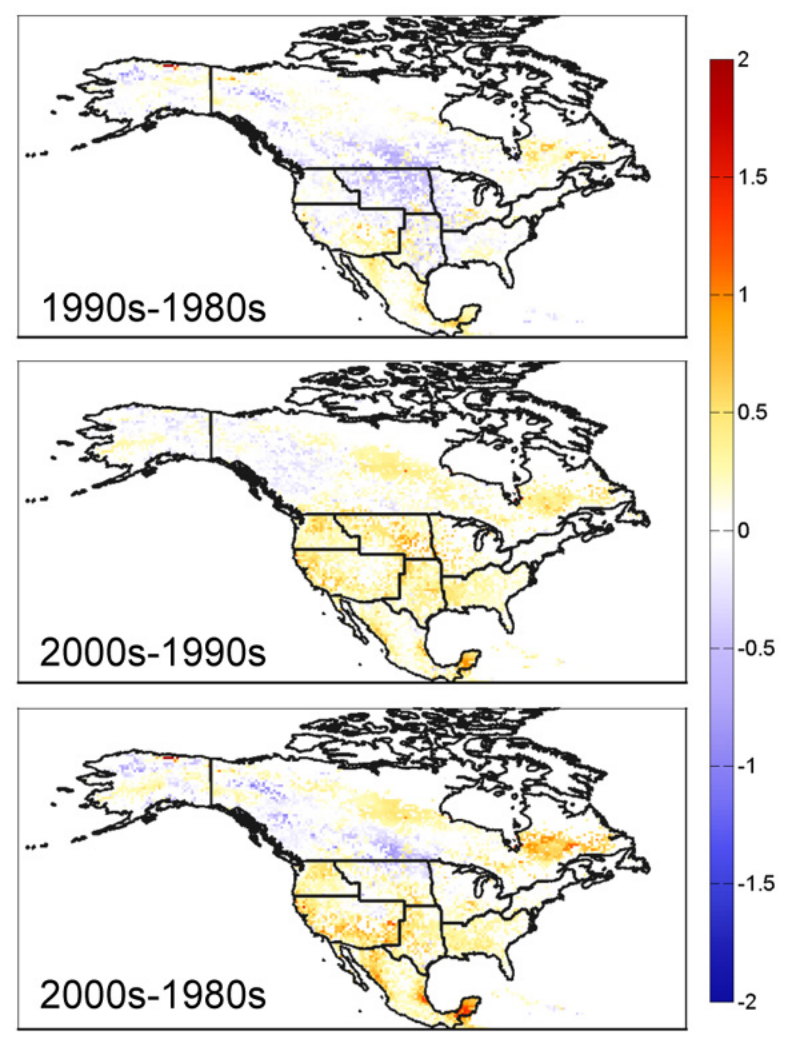

Fig. 12. Difference in decadal mean fire season PE for the 1980s, 1990s, and 2000s (mm day $\left.{ }^{-1}\right)$. Cells without GFED BA area in any year (1997-2010) appear white.

and the duration of fire activity may differ (Abatzoglou and Kolden, 2011), or be self-reinforcing through rainfall inhibition from biomass burning aerosols (Tosca et al., 2010; Rosenfeld, 1999). Daily BA and climate information can help isolate climate conditions that favour ignition, growth, and suppression of fire activities to better target mitigation and adaptation efforts on a regional basis. Third, other climate phenomena, such as changes in atmospheric circulation (Skinner et al., 1999; Macias Fauria and Johnson, 2006), may provide a more mechanistic representation of the evolution of warm, dry conditions that promote fire activity at mid-high latitudes. Future efforts to capture changing atmospheric circulation as a function of sea surface temperature anomalies (e.g., Duffy et al., 2005; Chen et al., 2011) may provide an alternate means to assess seasonal or long-term changes of fire risk in the US and other regions. Fourth, some local interactions between climate and fire were not well captured in this study, such as the role of snowpack for fire activity at the watershed scale (Westerling et al., 2006). BA and climate data on finer spatial scales may be needed to isolate climate-fire relationships in ecosystems with complex terrain or hydrology. Finally, the use of NCA administrative regions in this study may have masked climate-fire relationships for specific biomes (Littell et al., 2009) or other sub-regions where land cover, land use, or fragmentation are strong controls on BA.

This study represents the first national assessment of climate-fire relationships in the US. The MTBS (26 yr) and GFED time series (14 yr) of satellite BA data provide complementary information to evaluate the consistency of climate-fire relationships on a regional basis. Spatial patterns of BA in the US are complex, based on the diversity of fire types, ecosystems, and ignition sources within each NCA region. We document a significant increase in US BA during 1984-2009. Fire season PE also increased during this period, suggesting that stronger climate control on $\mathrm{BA}$ is one potential driver of recent BA trends in the western US and Alaska. Non-climate drivers of regional BA were also important for the seasonal and interannual variability of fire activity across the southern US. Differences between GFED and MTBS burned area estimates and weaker climate-fire relationships with GFED BA suggest a significant contribution from agricultural management fires in the SP and SE regions. This satellite-based assessment of US fire activity provides a foundation for future work on the regional sensitivity of US BA to climate change. Mid-term projections of future fire activity may benefit from the regional characterization of climate-fire relationships in this study, as climate-driven fire activity reflects existing fuel loads rather than the coupled response of vegetation growth and fire disturbance rates to future climate conditions.

Acknowledgements. This work was supported by NASA through a research award for science in support of the National Climate Assessment and NASA Grants NNX08AF64G and NNX10AT83G. We thank Ruth DeFries and Guido van der Werf for helpful comments on a previous version of this manuscript.

Edited by: P. Stoy

\section{References}

Abatzoglou, J. T. and Kolden, C. A.: Relative importance of weather and climate on wildfire growth in interior Alaska, Int. J. Wildland Fire, 20, 479-486, 2011.

Allen, R. G., Pereira, L. S., Raes, D., and Smith, M.: Crop evapotranspiration - guidelines for computing crop water requirements, Food and Agriculture Organization of the United Nations, Rome, 1998.

Andreae, M. O. and Merlet, P.: Emission of trace gases and aerosols from biomass burning, Global Biogeochem. Cy., 15, 955-966, 2001.

Arora, V. K. and Boer, G. J.: Fire as an interactive component of dynamic vegetation models, Geophys. Res. Lett., 110, G02008, doi:10.1029/2005JG000042, 2005.

Bachelet, D., Lenihan, J. M., Neilson, R. P., Drapek, R., and Kittel, T.: Simulated the response of natural ecosystems and their fire regimes to climatic variability in Alaska, Can. J. Forest Res., 35, 2244-2257, 2005. 
Balshi, M. S., McGuire, A. D., Duffy, P. A., Flannigan, M. D., Walsh, J., and Melillo, J.: Assessing the response of area burned to changing climate in western boreal North America using a multivariate adaptive regression splines (MARS) approach, Global Change Biol., 15, 578-600, 2009.

Bartlein, P. J., Hostetler, S. W., Schafer, S. L., Holman, J. O., and Solomon, A. M.: Temporal and spatial structure in a daily wildfire-start data set from the western United States (19861996), Int. J. Wildland Fire, 17, 8-17, 2008.

Bonan, G. B.: Forests and climate change: Forcings, feedbacks, and the climate benefits of forests, Science, 320, 1444-1449, 2008.

Bowman, D. M. J. S., Balch, J. K., Artaxo, P., Bond, W. J., Carlson, J. M., Cochrane, M. A., D’Antonio, C. M., DeFries, R. S., Doyle, J. C., Harrison, S. P., Johnston, F. H., Keeley, J. E., Krawchuk, M. A., Kull, C. A., Marston, J. B., Moritz, M. A., Prentice, I. C., Roos, C. I., Scott, A. C., Swetnam, T. W., van der Werf, G. R., and Pyne, S. J.: Fire in the Earth system, Science, 324, 481-484, doi:10.1126/science.1163886, 2009.

Bowman, D. J. S., Balch, J., Artaxo, P., Bond, W. J., Cochrane, M. A., D’Antonio, C. M., DeFries, R. S., Johnston, F. H., Keeley, J. E., Krawchuk, M. A., Kull, C. A., Mack, M., Moritz, M. A., Pyne, S., Roos, C. I., Scott, A. C., Sodhi, N. S., and Swetnam, T. W.: The human dimension of fire regimes on Earth, J. Biogeogr., 38, 2223-2236, doi:10.1111/j.1365-2699.2011.02595.x, 2011.

Brown, T. J., Hall, B. L., and Westerling, A. L.: The impact of twenty-first century climate change on wildland fire danger in the western United States: An applications perspective, Clim. Change, 62, 365-388, 2004.

Busch, D. E. and Smith, S. D.: Effects of fire on water and salinity relations of riparian woody taxa, Oecologia, 94, 186-194, 1993.

CCSP: Weather and climate extremes in a changing climate, Regions of focus: North America, Hawaii, Caribbean, and US Pacific Islands, A report by the US Climate change science program and the subcommittee on global change research, Department of commerce, Noaa's National Climatic Data Center, Washington, DC, 164 pp., 2008.

Chen, Y., Randerson, J. T., Morton, D. C., DeFries, R. S., Collatz, G. J., Kasibhatla, P. S., Giglio, L., Jin, Y., and Marlier, M. E.: Forecasting fire season severity in South America using sea surface temperature anomalies, Science, 334, 787-791, 2011.

Christian, H. J., Blakeslee, R. J., Boccippio, D. J., Boeck, W. L., Buechler, D. E., Driscoll, K. T., Goodman, S. J., Hall, J. M., Koshak, W. J., Mach, D. M., and Steward, M. F.: Global frequency and distribution of lightning as observed from space by the optical transient detector, J. Geophys. Res., 108, D14005, doi:10.1029/2002JD002347, 2003.

Chuvieco, E., Giglio, L., and Justice, C.: Global characterization of fire activity: Toward defining fire regimes from Earth observation data, Global Change Biol., 14, 1488-1502, 2008.

Duffy, P. A., Walsh, J. E., Graham, J. M., Mann, D. H., and Rupp, T. S.: Impacts of large-scale atmospheric-ocean variability on Alaskan fire season severity, Ecol. Appl., 15, 1317-1330, 2005.

Eidenshink, J., Schwind, B., Brewer, K., Zhu, Z.-L., Quayle, B., and Howard, S.: A project for monitoring trends in burn severity, Fire Ecology Special Issue, 3, 3-21, 2007.

Flannigan, M. D., Logan, K. A., Amiro, B. D., Skinner, W. R., and Stocks, B. J.: Future area burned in Canada, Clim. Change, 72, 1-16, doi:10.1007/s10584-005-5935-y, 2005.
Giglio, L.: Characterization of the tropical diurnal fire cycle using VIRS and MODIS observations, Remote Sens. Environ., 108, 407-421, 2007.

Giglio, L., Csiszar, I., and Justice, C. O.: Global distribution and seasonality of active fires as observed with the Terra and Aqua MODIS sensors, J. Geophys. Res., 111, 4005, doi:10.1029/2005JG000142, 2006.

Giglio, L., Randerson, J. T., van der Werf, G. R., Kasibhatla, P. S., Collatz, G. J., Morton, D. C., and DeFries, R. S.: Assessing variability and long-term trends in burned area by merging multiple satellite fire products, Biogeosciences, 7, 1171-1186, doi:10.5194/bg-7-1171-2010, 2010.

Gillett, N. P., Weaver, A. J., Zwiers, F. W., and Flannigan, M. D.: Detecting the effect of climate change on Canadian forest fires, Geophys. Res. Lett., 31, L18211, doi:10.1029/2004GL020876, 2004.

Girardin, M. P. and Wooton, B. M.: Summer moisture and wildfire risks across Canada, J. Appl. Meteorol. Climatol., 48, 517-533, 2009.

Girod, C. M., Hurtt, G. C., Frolking, S. E., Aber, J. D., and King, A. W.: The tension between fire risk and carbon storage: Evaluating US carbon and fire mitigation strategies through ecosystem models, Earth Interact., 11, pp. 33, 2007.

Golding, N. and Betts, R.: Fire risk in Amazonia due to climate change in the HadCM3 climate model: Potential interactions with deforestation, Global Biogeochem. Cy., 22, GB4007, doi:10.1029/2007GB003166, 2008.

Grissino-Mayer, H. D. and Swetnam, T. W.: Century-scale climate forcing of fire regimes in the American southwest, The Holocene, 10, 213-220, 2000.

Heyerdahl, E. K., Brubaker, L. B., and Agee, J. K.: Annual and decadal climate forcing of historical fire regimes in the interior Pacific Northwest, USA, The Holocene, 12, 597-604, 2002.

Kang, S., Kimball, J. S., and Running, S. W.: Simulating effects of fire disturbance and climate change on boreal forest productivity and evapotranspiration, Sci. Total Environ., 362, 85-102, 2006.

Kasischke, E. S. and Turetsky, M. R.: Recent changes in the fire regime across the North American boreal region: Spatial and temporal patterns of burning across Canada and Alaska, Geophys. Res. Lett., 33, L09703, doi:10.1029/2006GL025677, 2006.

Kasischke, E. S., Williams, D., and Barry, D.: Analysis of the patterns of large fires in the boreal forest region of Alaska, Int. J. Wildland Fire, 11, 131-144, 2002.

Kitzberger, T., Brown, P. M., Heyerdahl, E. K., Swetnam, T. W., and Veblen, T. T.: Contingent Pacific-Atlantic ocean influence on multicentury wildfire synchrony over western North America, P. Natl. Acad. Sci., 104, 543-548, 2007.

Kloster, S., Mahowald, N. M., Randerson, J. T., Thornton, P. E., Hoffman, F. M., Levis, S., Lawrence, P. J., Feddema, J. J., Oleson, K. W., and Lawrence, D. M.: Fire dynamics during the 20th century simulated by the community land model, Biogeosciences, 7, 1877-1902, doi:10.5194/bg-7-1877-2010, 2010.

Kloster, S., Mahowald, N. M., Randerson, J. T., and Lawrence, P. J.: The impacts of climate, land use, and demography on fires during the 21 st century simulated by CLM-CN, Biogeosciences, 9, 509-525, doi:10.5194/bg-9-509-2012, 2012.

Krawchuk, M. A., Moritz, M. A., Parisien, M.-A., Van Dorn, J., and Hayhoe, K.: Global pyrogeography: The current and future distribution of wildfire, PLoS One, 4, e5102. 
doi:5110.1371/journal.pone.0005102, 2009.

Lavorel, S., Flannigan, M. D., Lambin, E. F., and Scholes, M. C.: Vulnerability of land systems to fire: Interactions among humans, climate, the atmosphere, and ecosystems, Earth Environ. Sci., 12, 33-53, 2007.

Le Page, Y., Oom, D., Silva, J. M. N., Jönsson, P., and Pereira, J. M. C.: Seasonality of vegetation fires as modified by human action: Observing the deviation from eco-climatic fire regimes, Global Ecol. Biogeogr., 19, 575-588, 2010.

Lenihan, J. M., Bachelet, D., Neilson, R. P., and Drapek, R.: Simulated response of conterminous United States ecosystems to climate change at different levels of fire suppression, $\mathrm{CO}_{2}$ emission rate, and growth response to $\mathrm{CO}_{2}$, Global Planet. Change, 64, 16-25, 2008.

Littell, J. S., McKenzie, D., Peterson, D. L., and Westerling, A. L.: Climate and wildfire area burned in western US Ecoprovinces 1916-2003, Ecol. Appl., 19, 1003-1021, 2009.

Lu, J. B., McNulty, S. G., and Amatya, D. M.: A comparison of six potential evapotranspiration methods for regional use in the southeastern United States, J. Am. Water Resour. As., 41, 621633, 2005.

Macias Fauria, M. and Johnson, E. A.: Large-scale climatic patterns control large lightning fire occurrence in Canada and Alaska forest regions, J. Geophys. Res.-Atmos., 111, G04008, doi:10.1029/2006JG000181, 2006.

Magi, B. I., Rabin, S., Shevliakova, E., and Pacala, S.: Separating agricultural and non-agricultural fire seasonality at regional scales, Biogeosciences, 9, 3003-3012, doi:10.5194/bg-9-30032012, 2012.

Malhi, Y., Roberts, J. T., Betts, R., Killeen, T. J., Li, W., and Nobre, C. A.: Climate change, deforestation, and the fate of the Amazon, Science, 319, 169-172, 2008.

Marlon, J. R., Bartlein, P. J., Carcaillet, C., Gavin, D. G., Harrison, S. P., Higuera, P. E., Joos, F., Power, M. J., and Prentice, I. C.: Climate and human influences on global biomass burning over the past two millennia, Nat. Geosci., 1, 697-702, 2009.

McCarty, J., Justice, C. O., and Korontzi, S.: Agricultural burning in the southeastern United States detected by MODIS, Remote Sens. Environ., 108, 151-162, 2007.

McKenzie, D., Gedalof, Z., Peterson, D. L., and Mote, P.: Climatic change, wildfire, and conservation, Conserv. Biol., 18, 890-902, 2004.

Mesinger, F., DiMego, G., Kalnay, E., Mitchell, K., Shafran, P. C., Ebisuzaki, W., Jovic, D., Woollen, J., Rogers, E., Berbery, E. H., Ek, M. B., Fan, Y., Grumbine, R., Higgins, W., Li, H., Lin, Y., Manikin, G., Parrish, D., and Shi, W.: North American regional reanalysis, B. Am. Meteorol. Soc., 87, 343-360, 2006.

Morton, D. C., DeFries, R. S., Randerson, J. T., Giglio, L., Schroeder, W., and Van der Werf, G. R.: Agricultural intensification increases deforestation fire activity in Amazonia, Global Change Biol., 14, 2262-2275, 2008.

Mu, M., Randerson, J. T., van der Werf, G. R., Giglio, L., Kasibhatla, P. S., Morton, D. C., Collatz, G. J., DeFries, R. S., Hyer, E. J., Prins, E. M., Griffith, D. W. T., Wunch, D., Toon, G. C., Sherlock, V., and Wennberg, P. O.: Daily and hourly variability in global fire emissions and consequences for atmospheric model predictions of carbon monoxide, J. Geophys. Res.-Atmos., 116, D24303, doi:10.1029/2011JD016245, 2011.
O'Connor, C. D., Garfin, G. M., Falk, D. A., and Swetnam, T. W.: Human pyrogeography: A new synergy of fire, climate and people is reshaping ecosystems across the globe, Geography Compass, 5, 329-350, doi:10.1111/j.1749-8198.2011.00428.x, 2011.

Parisien, M.-A., Parks, S. A., Krawchuk, M. A., Flannigan, M. D., Bowman, L. M., and Moritz, M. A.: Scale-dependent controls on the area burned in the boreal forest of Canada, 1980-2005, Ecol. Appl., 21, 789-805, 2011.

Pechony, O. and Shindell, D. T.: Driving forces of global wildfires over the past millennium and the forthcoming century, P. Natl. A. Sci. USA, 107, 19167-19170, doi:10.1073/pnas.1003669107, 2010.

Randerson, J. T., Liu, H., Flanner, M. G., Chambers, S. D., Jin, Y., Hess, P. G., Pfister, G., Mack, M., Treseder, K. K., Welp, L. R., Chapin III, F. S., Harden, J. W., Goulden, M. L., Lyons, E., Neff, J. C., Schuur, E. A. G., and Zender, C. S.: The impact of boreal forest fire on climate warming, Science, 314, 1130-1132, 2006.

Rogers, B. M., Neilson, R. P., Drapek, R., Lenihan, J. M., Wells, J. R., Bachelet, D., and Law, B. E.: Impacts of climate change on fire regimes and carbon stocks in the US Pacific Northwest, J. Geophys. Res., 116, G03037, doi:10.1029/2011JG001695, 2011.

Rosenfeld, D.: TRMM observed first direct evidence of smoke from forest fires inhibiting rainfall, Geophys. Res. Lett., 26, 31053108, 1999.

Rothermel, R.: A mathematical model for predicting fire spread in wildand fuels, forest service general technical report int-115, in, Forest Service General Technical Report INT-115, Intermountain Forest and Range Experiment Station, Forest Service, US Department of Agriculture, 1972.

Roy, D. P., Boschetti, L., Justice, C. O., and Ju, J.: The collection 5 MODIS burned area product - global evaluation by comparison with the MODIS burned area product, Remote Sens. Environ., 112, 3690-3707, 2008.

Schoennagel, T., Veblen, T. T., Romme, W. H., Sibold, J. S., and Cook, E. R.: ENSO and PDO variability affect droughtinduced fire occurrence in Rocky Mountain subalpine forests, Ecol. Appl., 15, 2000-2014, 2005.

Scholze, M., Knorr, W., Arnell, N. W., and Prentice, I. C.: A climate-change risk analysis for world ecosystems, P. Natl. A. Sci. USA, 103, 13116-13120, 2006.

Scott, J. H. and Burgan, R. E.: Standard fire behavior fuel models: A comprehensive set for use with Rothermel's surface fire spread model, in: USDA-Forest Service, Rocky Mountain Research Station, 2005.

Seiler, W. and Crutzen, P. J.: Estimates of gross and net fluxes of carbon between the biosphere and atmosphere from biomass burning, Clim. Change, 2, 207-247, 1980.

Skinner, W. R., Stocks, B. J., Martell, D. L., and Shabbar, A.: The association between circulation anomalies in the midtroposphere and area burned by wildland fire in Canada, Theoretical Applied Climatology, 63, 89-105, 1999.

Spraklen, D. V., Mickley, L. J., Loga, J. A., Hudman, R. C., Yevich, R., Flannigan, M. D., and Westerling, A. L.: Impacts of climate change from 2000 to 2050 on wildfire activity and carbonaceous aerosol concentrations in the western United States, J. Geophys. Res., 114, D20301, doi:20310.21029/22008JD010966, 2009.

Swetnam, T. W. and Betancourt, J. L.: Fire-southern oscillation relations in the Southwestern United States, Science, 249, 1017$1020,1990$. 
Taylor, A. H. and Beaty, R. M.: Climatic influences on fire regiomes in the northern Sierra Nevada Mountains, Lake Tahoe Basin, Nevada, USA, J. Biogeogr., 32, 425-438, 2005.

Thonicke, K., Spessa, A., Prentice, I. C., Harrison, S. P., Dong, L., and Carmona-Morena, C.: The influence of vegetation, fire spread and fire behaviour on biomass burning and trace gas emissions: Results from a process-based model, Biogeosciences, 7, 1991-2011, doi:10.5194/bg-7-1991-2010, 2010.

Tosca, M. G., Randerson, J. T., Zender, C. S., Flanner, M. G., and Rasch, P. J.: Do biomass burning aerosols intensify drought in equatorial Asia during El Niño?, Atmos. Chem. Phys., 10, 35153528, doi:10.5194/acp-10-3515-2010, 2010.

Trouet, V., Taylor, A. H., Carleton, A. M., and Skinner, C. N.: Fireclimate interactions in forests of the American Pacific Coast, Geophys. Res. Lett., 33, L18704, doi:10.1029/2006GL027502, 2006.

USGCRP: Global climate impacts in the United States, Cambridge University Press, 2009.

van der Werf, G. R., Dempewolf, J., Trigg, S. N., Randerson, J. T., Kasibhatla, P., Giglio, L., Murdiyarso, D., Peters, W., Morton, D. C., Collatz, G. J., DeFries, R. S., and Dolman, H.: Climate regulation of fire emissions and deforestation in Equatorial Asia, P. Natl. A. Sci. USA, 105, 20350-20355, 2008a.

van der Werf, G. R., Randerson, J. T., Giglio, L., Gobron, N., and Dolman, A. J.: Climate controls on the variability of fires in the tropics and subtropics, Global Biogeochem. Cy., 22, GB3028, doi:3010.1029/2007GB003122, 2008b.

van der Werf, G. R., Randerson, J. T., Giglio, L., Collatz, G. J., Mu, M., Kasibhatla, P. S., Morton, D. C., DeFries, R. S., Jin, Y., and van Leeuwen, T. T.: Global fire emissions and the contribution of deforestation, savanna, forest, agricultural, and peat fires (19972009), Atmos. Chem. Phys., 10, 11707-11735, doi:10.5194/acp10-11707-2010, 2010.
Veblen, T. T., Kitzberger, T., and Donnegan, J.: Climatic and human influences on fire regimes in ponderosa pine forests in the Colorado Front Range, Ecol. Appl., 10, 1178-1195, 2000.

Westerling, A. L., Gershunov, A., Cayan, D. R., and Barnett, T. P.: Long lead statistical forecasts of area burned in western US wildfires by ecosystem province, Int. J. Wildland Fire, 11, 257-266, 2002.

Westerling, A. L., Gershunov, A., Brown, T. J., Cayan, D. R., and Dettinger, M. D.: Climate and wildfire in the western United States, B. Am. Meteorol. Soc., 85, 595-604, 2003.

Westerling, A. L., Hidalgo, H. G., Cayan, D. R., and Swetnam, T. W.: Warming and earlier spring increase western us forest wildfire activity, Science, 313, 940-943, 2006.

Westerling, A. L., Bryant, B. P., Preisler, H. K., Holmes, T. P., Hidalgo, H. G., Das, T., and Shrestha, S. R.: Climate change and growth scenarios for California wildfire, Clim. Change, 109, 445-463, 2011a.

Westerling, A. L., Turner, D. P., Smithwick, E. A. H., Romme, W. H., and Ryan, M. G.: Continued warming could transform Greater Yellowstone fire regimes by mid21st century, P. Natl. Acad. Sci. USA, 108, 13165-13170, doi:10.1073/pnas.1110199108, 2011b.

Xiao, J. and Zhuang, Q.: Drought effects on large fire activity in Canadian and Alaskan forests, Environ. Res. Lett., 2, 044003, doi:10.1088/1748-9326/2/4/044003, 2007. 